\title{
DOMINANT CULTURABLE BACTERIAL MICROBIOTA IN THE DIGESTIVE TRACT OF THE AMERICAN BLACK VULTURE (CORAGYPS ATRATUS BECHSTEIN 1793) AND SEARCH FOR ANTAGONISTIC SUBSTANCES
}

\author{
Lydston Rodrigues de Carvalho; Luiz Macêdo Farias; Jacques Robert Nicoli*; Maria Clara Fernandes Silva; \\ Andrea Teresa Santos Meira Corsino; Luiz André de Lima; Rodrigo Aparecido Fernandes Redondo; \\ Paulo César Peregrino Ferreira; Maria Elizabeth Bernardes Margutti Pinto
}

\author{
Departamento de Microbiologia, Instituto de Ciências Biológicas, Universidade Federal de Minas Gerais, Belo Horizonte, \\ Minas Gerais, Brasil.
}

Submitted: November 17, 2000; Returned to Authors: July 25, 2001; Approved June 08, 2003

\begin{abstract}
Strict and facultative culturable anaerobic bacteria from the digestive tract of six American black vultures (Coragyps atratus Bechstein 1793) were isolated and identified. After capture, the birds received a noncontaminated diet for one week to eliminate possible allochthonous microorganisms. Then, specimens collected from tongue, stomach and intestines were weighed, submitted to decimal dilution in an anaerobic chamber, inoculated into culture media and incubated aerobically and anaerobically at $37^{\circ} \mathrm{C}$ for enumeration, isolation and identification. Isolated bacteria were submitted to tests to detect possible antagonisms between them. The total bacterial population along the digestive tract ranged from $3.46 \pm 0.39 \log \mathrm{CFU} / \mathrm{g}$ in the stomach to $10.75 \pm 0.37 \log \mathrm{CFU} / \mathrm{g}$ in the distal intestine. Some bacteria were isolated for the first time from the digestive tract of C. atratus: Actinomyces bovis, Lactobacillus cellobiosus, Micrococcus luteus, Neisseria sicca, Clostridium bifermentans, Enterobacter agglomerans, Peptostreptococcus sp., Sarcina sp., Serratia odorifera, and Shigella flexneri. Associations between microorganisms were observed during isolation on two occasions, one involving $A$. bovis and $N$. sicca, and the other involving A. bovis and a Gram-negative rod. Hetero-, iso- and autoantagonisms were observed, suggesting the ecological role of these indigenous microorganisms in terms of population auto-control and environmental barrier in the digestive tract of carrionfeeding birds.
\end{abstract}

Key words: Culture, microbiota, digestive tract, antagonistic substance.

\section{INTRODUCTION}

The American black vulture (Coragyps atratus BECHSTEIN 1793) is a bird highly associated with human activity, having an ample geographic distribution throughout the American Continent. Its scavenging habits make the bird an interesting subject of study, especially for its bacteriologic characteristics. Since scavenging birds feed regularly on decaying carcasses of animals that have succumbed to infectious diseases, the thought arose that these birds probably were highly resistant to pathogenic microorganisms and their toxins. As examples, in scavenging birds high resistance against Bacillus anthracis (12) and oral doses of Clostridium botulinum toxin, normally lethal for other animals, have been demonstrated (7).

Several mechanisms may explain this resistance: a) the specific absorption mechanism in the digestive tract of the bird; b) the physicochemical and physiological conditions in the digestive system ( $\mathrm{pH}$, oxygen concentration, intestinal transit), c) the constitution of the digestive epithelium, and/or d) the

*Corresponding author. Mailing address: Laboratório de Ecologia e Fisiologia de Microorganismos, Departamento de Microbiologia, Instituto de Ciências Biológicas, Universidade Federal de Minas Gerais. Caixa Postal 486. 30161-970, Belo Horizonte, MG, Brasil. Tel.: (+5531) 3499-2757. Fax: (+5531) 3499-2733. E-mail: jnicoli@mono.icb.ufmg.br. 
presence of a complex microbiota in the digestive ecosystem $(6,7,12,19,20)$. Anti-microbial agents may be secreted by the liver or gastric epithelium, or produced by microorganisms of the normal microbiota. Another hypothesis may be the modulation of the production and/or action of toxins by the indigenous microbiota and/or by the host. As an example, mortality and intestinal cytotoxin production during an experimental infection with Clostridium difficile were highly reduced in gnotobiotic mice previously inoculated with bacteria from the normal digestive ecosystem (3). Similarly, in the absence of indigenous microbiota, germfree animals are more susceptible to the botulinal neurotoxin (10).

The importance of the intestinal microbiota to the welfare of the host was recognized early in the history of microbiology. As a result, the nature of the gastrointestinal microbiota of many animal species is well documented in the literature. However, very few data exist on the digestive tract microbiota of carrion-feeding birds in general and C. atratus in particular. In the few studies found in the literature on the fecal microbiota of the Whiteback griffon vulture (Gyps africanus) and C. atratus $(6,19)$, the focus was generally more epidemiological than bacteriologic, except for a report on Cathartes aura (20). Moreover, none of these studies involved qualitative or quantitative determinations of the bacteria present in the various portions of the digestive tract or distinguished the autochthonous from the allochthonous microbiota.

The present study concerns the enumeration, isolation and identification of the culturable indigenous microbiota in the digestive tract of the American black vulture (C. atratus), as well as antagonistic substances produced by the isolated bacteria.

\section{MATERIALS AND METHODS}

\section{Birds}

Six adult $C$. atratus vultures were utilized in this study. The birds were captured using a rope-trap in Contagem, Belo Horizonte and Ibiá areas, Minas Gerais state, Brazil, after special scientific collecting permits were obtained from the Instituto Brasileiro do Meio Ambiente e dos Recursos Naturais Renováveis (IBAMA license 021/96, protocol P-15640/94). In order to eliminate possible allochthonous microorganisms, the birds were fed a non-contaminated controlled diet for six days before sacrifice by ether inhalation. This diet consisted of tap water and bovine meat (lung) inspected by the Sanitary Surveillance for the absence of pathogenic microorganisms according to current legislation. The meat was kept under refrigeration in the laboratory and, before being offered to the birds, was submitted to superficial decontamination under UV for $20 \mathrm{~min}$. The meat was manipulated with the use of gloves and sterilized material for cutting the pieces to be offered $(10 \mathrm{~cm}$ long and 3 to $4 \mathrm{~cm}$ wide).

\section{Necropsy}

Before sacrifice, the birds were examined for general health aspects (general appearance, mucosal appearance and physical integrity) by one of the author (L. A. Lima, VMD), looking for any sign of disease or pathology. The necropsy was performed under a laminar flow hood where the entire digestive tract of the birds was removed with the extremities closed. Sets of sterilized dissection instruments were utilized for each portion of the digestive tract to avoid cross-contamination and fragments of the tongue, stomach and intestines were removed. Due to the absence of histologic information about the digestive tract of C. atratus, an arbitrary subdivision of the intestines was adapted from the study of Salanitro et al. (18). The intestines, which had an average length of $120 \mathrm{~cm}$, were divided into proximal intestine (right below the stomach), medial intestine (approximately 40 $\mathrm{cm}$ after the stomach) and distal intestine (right above the cloaca). Each digestive tract fragment was $0.5 \mathrm{~cm}^{2}$ and was taken from equivalent portions of each bird.

\section{Enumeration}

The fragments were weighed, macerated in $2 \mathrm{~mL}$ of prereduced anaerobically sterilized fluid (Ringer-PRAS) and introduced into an anaerobic chamber containing $10 \% \mathrm{H}_{2}, 5 \%$ $\mathrm{CO}_{2}$ and $85 \% \mathrm{~N}_{2}$ (Forma Scientific Company, Marietta, OH, USA) where decimal dilutions were performed in regenerated sterile buffered saline. Amounts of $0.1 \mathrm{~mL}$ from each dilution were spread onto the following culture media: Blood Agar supplemented with hemine $(5 \mathrm{mg} / \mathrm{mL})$, menadione $(1 \mathrm{mg} / \mathrm{mL})$ and yeast extract $(0.5 \%)$, and Bacteroide Bile Esculine Agar (11). Portions of relevant dilutions were transferred from the chamber for plating onto Blood Agar and MacConkey Agar and subsequent aerobic incubation. The Petri dishes were incubated at $37^{\circ} \mathrm{C}$ for one week inside the anaerobic chamber, after which colonies were counted. Under aerobic conditions, the dishes were incubated at the same temperature for $24 \mathrm{~h}$. Total anaerobic counts and counts for each morphologically different colony on all media and atmospheric conditions were performed in duplicate.

\section{Isolation and identification of microorganisms}

After enumeration, the dishes containing 30 to 300 colonies were used to isolate three to four specimens of each colony presenting different macroscopic appearance. These different morphotypes were isolated on appropriate medium and submitted to microscopic examination, respiratory test and initial biochemical and physiological tests (catalase, oxidase and motility). Using the previous results as a guide, some microorganisms were inoculated into Adolfo Lutz Institute Medium (IAL) to obtain a presumptive identification for Gramnegative rods. Using a single tube of this medium, it is possible to determine indole production, L-tryptophan deamination, presence or absence of sucrose and glucose fermentation, gas 
production, $\mathrm{H}_{2} \mathrm{~S}$ production, urea hydrolysis, L-lysine decarboxylation and motility (15). Biochemical tests were also carried out using the API $20 \mathrm{~A}$, API 20 STREP and API $50 \mathrm{CH}$ identification system kits (bioMérieux, Marcy-l’Etoile, France) for anaerobes, streptococci and carbohydrate metabolism of microorganisms, respectively. The BBL Crystal E/NF identification system kit (Becton Dickinson Microbiology Systems, Cockeysville, MD, USA) was used for enterobacteria and non-fermentative microorganisms. Additional biochemical tests were done when necessary.

\section{Bacterial antagonism}

The bioassay for antagonistic diffusible substances was carried out by the double-layer method originally described by Kelner (8). The inoculum was prepared in Tryptic Soy Broth (TSB). Eighteen-hour cultures were spotted simultaneously with a micropipette ( $2 \mathrm{~mL}$ at equidistant points) onto the surface of basal Tryptic Soy Agar (TSA) layered on Petri dishes and allowed to dry. After incubation at $37^{\circ} \mathrm{C}$ for $18 \mathrm{~h}$, inside or outside the anaerobic chamber depending on the bacteria, the cells were killed by exposure to chloroform for $30 \mathrm{~min}$. Residual chloroform was allowed to evaporate and the Petri dishes were overlaid with $4 \mathrm{~mL}$ of TSA soft agar $(0.75 \%)$ which had been inoculated with $10 \mathrm{~mL}$ of a $24 \mathrm{~h}$ culture of the indicator strain. After $18 \mathrm{~h}$ of incubation at $37^{\circ} \mathrm{C}$ under aerobiosis or anaerobiosis, the plates were evaluated for the presence of zones of growth inhibition and the diameter of the halos were measured with the help of a caliper. To exclude the possibility of residual chloroform interference in the growth of indicator strains, the evaluation of antagonistic activity was performed without its use. The assays were performed by testing bacteria from the same digestive portion as producer and indicator strains. Hetero-, iso- and autoantagonisms were defined, respectively, as the growth inhibition of a producer strain against taxonomically unrelated strains, against isolates of the same species and against itself.

Three other indicator strains not belonging to the $C$. atratus digestive ecosystem were also utilized: Escherichia coli $\mathrm{K}_{12}$ Sm, Pseudomonas aeruginosa and Staphylococcus aureus ATCC 25923.

\section{RESULTS}

The total culturable indigenous microbiota varied throughout the digestive system of $C$. atratus. The mean population levels were of $6.52 \pm 0.14,3.46 \pm 0.39,7.98 \pm 0.49$, $10.16 \pm 0.40$ and $10.75 \pm 0.37 \log \mathrm{CFU} / \mathrm{g}$, respectively for the tongue, stomach, proximal intestine, medial intestine and distal intestine.

From the different portions of the digestive tract of the six birds, a total of 45 different bacteria of the dominant indigenous microbiota were isolated. These colonies were identified as belonging to thirteen different bacterial genera, corresponding to seventeen species. Table 1 shows the bacterial species isolated from each portion of the digestive tract of $C$. atratus and their respective population level and frequency. The following bacteria were found: Actinomyces bovis, Lactobacillus cellobiosus, Micrococcus luteus, Neisseria sicca, Staphylococcus epidermidis, Staphylococcus saprophyticus, Streptococcus pyogenes, Clostridium bifermentans, Clostridium sp., Enterobacter agglomerans, Escherichia coli, metabolically inactive Escherichia coli, Escherichia fergusonii, Peptostreptococcus sp., Sarcina sp., Serratia odorifera and Shigella flexneri. Metabolically inactive E. coli is defined (5) as an immobile Gram-negative rod glucose positive and negative for $\mathrm{H}_{2} \mathrm{~S}$ production, urease, lysine decarboxylase, gas production in carbohydrate fermentation and sucrose fermentation

During the bacterial isolation procedures, two strains recovered from two birds and apparently presenting a single macroscopic appearance proved, after Gram staining, to consist in fact of two different bacteria. In the first case, the association found in the tongue of one bird was between A. bovis and $N$. sicca. The second case of association consisted of A. bovis and a Gram-negative unidentified rod found in the proximal intestine of a second vulture. These associations were considerably stable, resisting to various attempts of separation. In the second association, the microorganisms were so intimately dependent that dissociation led to the death of one of them.

Table 2 shows only positive results obtained from the antagonistic assays using the 45 isolates from the digestive tract of $C$. atratus. In these experiments, all bacterial isolates from the same portion of the digestive tract were used as producer and indicator strains, being tested with themselves and to three bacterial reference strains. A total of 25 antagonistic activities (subdivided into 20 heteroantagonisms, two isoantagonisms and three autoantagonisms) were observed in the assays. For the most part, the antagonistic activity was present in enterobacteria (48\%), followed by staphylococci (32\%), A. bovis $(16 \%)$ and M. luteus (4\%). The antagonistic activities of enterobacteria were principally concentrated in the stomach and in the proximal and medial intestines, while antagonistic activities of staphylococci were only found on the tongue and in the distal intestine. No bacterial isolates of the same species (S. epidermidis, A. bovis, E. agglomerans, E. fergusonii, E. coli) obtained from different portions of the digestive tract showed the same antagonistic spectrum.

\section{DISCUSSION}

The absence of a specific methodology for the study of the digestive microbiota of wild birds, especially the scavenger ones, led us to adopt a classic procedure used for the investigation of the microbiota from domestic birds and mammals $(4,18)$. The controlled diet prescribed for the birds for 
Table 1. Bacteria isolated from different portion of the digestive tract of Coragyps atratus.

\begin{tabular}{|c|c|c|c|c|}
\hline $\begin{array}{l}\text { Digestive tract } \\
\text { portion }\end{array}$ & Bacteria & $\begin{array}{c}\text { Log CFU/g } \\
\text { ( } \pm \text { SD) }\end{array}$ & $\begin{array}{l}\text { Occurrence } \\
\text { /6 birds }\end{array}$ & Original site \\
\hline \multirow{7}{*}{ Tongue } & Actinomyces bovis & $6.56 \pm 0.02$ & 5 & $a, b, c, d, f$ \\
\hline & Lactobacillus cellobiosus & 6.78 & 1 & $\mathrm{~b}$ \\
\hline & Micrococcus luteus & 6.30 & 1 & $\mathrm{a}$ \\
\hline & Neisseria sicca & 6.57 & 1 & $\mathrm{~b}$ \\
\hline & Staphylococcus epidermidis & $6.46 \pm 0.04$ & 5 & $a, b, c, e, f$ \\
\hline & Staphylococcus saprophyticus & $6.43 \pm 0.04$ & 5 & $\mathrm{a}, \mathrm{b}, \mathrm{c}, \mathrm{e}, \mathrm{f}$ \\
\hline & Streptococcus pyogenes & $6.53 \pm 0.01$ & 2 & $\mathrm{c}, \mathrm{f}$ \\
\hline \multirow{9}{*}{ Stomach } & Actinomyces bovis & $3.34 \pm 0.34$ & 2 & $\mathrm{c}, \mathrm{e}$ \\
\hline & Clostridium bifermentans & 3.78 & 1 & $\mathrm{~b}$ \\
\hline & Clostridium $\mathrm{sp}$ & $3.27 \pm 0.06$ & 2 & $b, d$ \\
\hline & Enterobacter agglomerans & $4.35 \pm 0.13$ & 3 & $\mathrm{c}, \mathrm{e}, \mathrm{f}$ \\
\hline & Escherichia coli inactive & $3.11 \pm 0.07$ & 3 & $\mathrm{c}, \mathrm{e}, \mathrm{f}$ \\
\hline & Escherichia fergusonii & $3.40 \pm 0.03$ & 2 & $\mathrm{c}, \mathrm{d}$ \\
\hline & Peptostreptococcus sp & 3.26 & 1 & $\mathrm{~b}$ \\
\hline & Staphylococcus epidermidis & $3.41 \pm 0.02$ & 3 & $\mathrm{~b}, \mathrm{c}, \mathrm{d}$ \\
\hline & Streptococcus pyogenes & 3.0 & 1 & c \\
\hline \multirow[t]{10}{*}{ Proximal Intestine } & Clostridium bifermentans & 8.08 & 1 & $\mathrm{c}$ \\
\hline & Enterobacter agglomerans & $8.6 \pm 0.01$ & 2 & $a, b$ \\
\hline & Escherichia coli & $7.89 \pm 0.01$ & 2 & $b, f$ \\
\hline & Escherichia coli inactive & $7.9 \pm 0.03$ & 2 & $b, d$ \\
\hline & Escherichia fergusonii & $8.39 \pm 0.07$ & 4 & $a, c, e, f$ \\
\hline & Lactobacillus cellobiosus & $7.18 \pm 0.03$ & 3 & $c, e, f$ \\
\hline & Peptostreptococcus $\mathrm{sp}$ & 8.60 & 1 & $\mathrm{~d}$ \\
\hline & Sarcina $\mathrm{sp}$ & 7.28 & 1 & $\mathrm{c}$ \\
\hline & Serratia odorifera & 7.51 & 1 & $\mathrm{~b}$ \\
\hline & Staphylococcus epidermidis & $8.36 \pm 0.04$ & 3 & $c, e, f$ \\
\hline \multirow[t]{10}{*}{ Medial Intestine } & Actinomyces bovis & 10.08 & 1 & $\mathrm{c}$ \\
\hline & Clostridium bifermentans & 9.95 & 1 & $\mathrm{~b}$ \\
\hline & Enterobacter agglomerans & $10.52 \pm 0.09$ & 4 & $b, c, d, f$ \\
\hline & Escherichia coli & $9.20 \pm 0.09$ & 4 & $\mathrm{~b}, \mathrm{~d}, \mathrm{e}, \mathrm{f}$ \\
\hline & Escherichia fergusonii & $10.53 \pm 0.06$ & 2 & $\mathrm{~b}, \mathrm{e}$ \\
\hline & Micrococcus luteus & 10.08 & 1 & $\mathrm{c}$ \\
\hline & Peptostreptococcus sp & $10.55 \pm 0.04$ & 2 & $c, d$ \\
\hline & Shigella flexneri & 10.08 & 1 & $\mathrm{c}$ \\
\hline & Staphylococcus epidermidis & $10.19 \pm 0.12$ & 2 & $\mathrm{c}, \mathrm{d}$ \\
\hline & Staphylococcus saprophyticus & 10.38 & 1 & d \\
\hline \multirow[t]{9}{*}{ Distal Intestine } & Actinomyces bovis & 11.36 & 1 & $\mathrm{~d}$ \\
\hline & Clostridium $\mathrm{sp}$ & 10.95 & 1 & $\mathrm{e}$ \\
\hline & Enterobacter agglomerans & $11.21 \pm 0.08$ & 2 & $\mathrm{~d}, \mathrm{f}$ \\
\hline & Escherichia coli & $10.27 \pm 0.19$ & 3 & $a, b, f$ \\
\hline & Escherichia coli inactive & $10.90 \pm 0.01$ & 2 & $\mathrm{~b}, \mathrm{e}$ \\
\hline & Escherichia fergusonii & $10.54 \pm 0.04$ & 2 & $\mathrm{~d}, \mathrm{e}$ \\
\hline & Peptostreptococcus sp & $10.52 \pm 0.03$ & 3 & $\mathrm{c}, \mathrm{d}, \mathrm{e}$ \\
\hline & Staphylococcus epidermidis & 10.43 & 1 & $\mathrm{~b}$ \\
\hline & Staphylococcus saprophyticus & $10.53 \pm 0.09$ & 4 & $\mathrm{~b}, \mathrm{c}, \mathrm{e}, \mathrm{f}$ \\
\hline
\end{tabular}

$\mathrm{a}=$ bird \#1, captured in March $26^{\text {th }} 1996$ at BHZOO, Belo Horizonte / Minas Gerais;

b = bird \#2, captured in July $18^{\text {th }} 1996$ at Fazenda da Lage, Ibiá / Minas Gerais;

c = bird \#3, captured in August $30^{\text {th }} 1996$ at Fazenda da Lage, Ibiá / Minas Gerais;

$\mathrm{d}=$ bird \#4, captured in January $31^{\text {st }} 1997$ at Garbage deposit in Nova Contagem, Contagem / Minas Gerais;

$\mathrm{e}=$ bird \#5, captured in March $27^{\text {th }} 1997$ at Garbage deposit in Nova Contagem, Contagem / Minas Gerais;

$\mathrm{f}=$ bird \#6, captured in May 06 1997 at Garbage deposit in Nova Contagem, Contagem / Minas Gerais. 
Table 2. Antagonism between bacteria isolated from different portions of the digestive tract of Coragyps atratus and against three reference strains.

\begin{tabular}{|c|c|c|c|}
\hline \multirow[t]{2}{*}{ Portion } & \multirow[t]{2}{*}{ Producer strain } & \multicolumn{2}{|c|}{ Indicator strain (halo diameter in $\mathbf{m m}$ ) } \\
\hline & & Isolated strain & Reference strain \\
\hline \multirow[t]{5}{*}{ Tongue } & S. epidermidis & A. bovis (33) & P.aeruginosa (35) \\
\hline & & S. epidermidis (28) & S. aureus (41) \\
\hline & & S. saprophyticus (24) & E. coli K12 (29) \\
\hline & A. bovis & S. saprophyticus (23) & P. aeruginosa $(27)$ \\
\hline & M. luteus & S. saprophyticus (18) & \\
\hline \multirow{3}{*}{ Stomach } & E. agglomerans & E. agglomerans (15) & \\
\hline & E. fergusonii & E. agglomerans (34) & S. aureus (56) \\
\hline & & S. pyogenes $(22)$ & E. coli $\mathrm{K} 12(51)$ \\
\hline \multirow[t]{3}{*}{ Proximal intestine } & E. agglomerans & & P. aeruginosa (29) \\
\hline & E. coli inactive & E. $\operatorname{coli}(35)$ & \\
\hline & E. fergusonii & & E. coli $\mathrm{K} 12(26)$ \\
\hline Median intestine & E. coli & $\begin{array}{l}\text { A. bovis (26) } \\
M \text { luteus (61) }\end{array}$ & E. coli $\mathrm{K} 12(58$ \\
\hline \multirow[t]{4}{*}{ Distal intestine } & A. bovis & & E. coli $\mathrm{K} 12(30)$ \\
\hline & E. coli & A. bovis (57) & \\
\hline & S. epidermidis & S. saprophyticus (29) & \\
\hline & S. saprophyticus & S. saprophyticus (13) & \\
\hline
\end{tabular}

six days before sacrifice was important to eliminate the presence of allochthonous microorganisms normally associated with the ingestion of decaying animal carcasses, allowing the isolation of solely components of the autochthonous microbiota from the digestive tract.

The quantitative variation of the total population of microorganisms throughout the digestive tract was similar to that observed in the digestive tract of carnivores and other animals $(14,16,17,18)$ with a higher concentration of microorganisms in the final portions of this tract. The lower level of the bacterial population in the stomach when compared to other birds and to non-human mammals (generally about $10^{7}-10^{8} \mathrm{CFU} / \mathrm{g}$ of contents) was probably due to the highly acidic environment. The gastric contents have been shown to have a $\mathrm{pH}$ of the order of 1.0-2.0, which is a general feature of carnivorous birds. Only the $\mathrm{pH}$ of digesting stomach contents in the heron (Ardea Cinerea), kestrel (Falco tinnunculus) and barn owl (Tyto alba) ranges from 2.5 to 5.0. As observed in humans, the highly acidic conditions of the $C$. atratus stomach probably contribute to the breakdown of food and also constitute a potent barrier against microbial pathogens. The progressive increase of total microbial counts along of the small intestine may be explained by the simultaneous decrease of the intestinal transit flow from the duodenum to the ileum allowing the expansion of microbial populations.

Two aspects of the digestive microbiota of the American black vulture are unusual (Table 1). First, the high population levels of staphylococci which are apparent constituents of the dominant microbiota in all the portions of the digestive tract (until $10^{10} \mathrm{CFU} / \mathrm{g}$ in the distal intestine). These bacteria are sometimes present in the gastrointestinal microbiota, even in humans, but generally at lower population levels of about $10^{3}-$ $10^{4} \mathrm{CFU} / \mathrm{g}$ (4). Staphylococci are more frequently found in the cutaneous and upper respiratory tract ecosystems. The second unusual fact observed in this study was the presence of enterobacteria in the dominant populations from the stomach to the distal intestine. In other animals (all mammals and other birds), the enterobacteria generally belong to the sub-dominant populations (about 10 to 1000 fold lower than the dominant ones). However, in the few studies on the digestive microbiota (non-quantitative data obtained only for feces) of scavenger birds, enterobacteria were always isolated $(6,19,20)$. Schlatter $e t$ al. (19), working with $C$. atratus in Chile, has also detected bacteria of the genera Escherichia, Staphylococcus and Streptococcus. Winsor et al. (20) also isolated and identified bacteria of the family Enterobacteriaceae from the intestinal microbiota of $C$. aura. The presence of enterobacteria in the digestive tract of domestic birds has been well described $(1,2,9,14,18)$. The presence of a high population level of S. flexneri in the median intestine of one bird supports the importance of carrion-feeding birds in the spreading of bacterial pathogens as observed in other studies $(6,19,20)$. Few anaerobic bacteria (Peptostreptococcus sp., Clostridium spp., Sarcina sp.) were found in the digestive tract of $C$. atratus but when observed, these microorganisms reached high population levels. In spite of the use of a selective medium for Bacteroides (11), bacteria 
from this genus were not isolated. The microbiota encountered in C. atratus demonstrated the similar presence of a large number of both Gram-negative rods and Gram-positive cocci. Among the bacteria isolated from the digestive tract of $C$. atratus, the following are reported for the first time: A. bovis, L. cellobiosus, $M$. luteus, N. sicca, C. bifermentans, E. agglomerans, Peptostreptococcus sp., Sarcina sp, S. odorifera and S. flexneri.

Among the 45 bacteria isolated from the digestive tract of $C$. atratus, thirteen (29\%) showed a certain level of antagonism. Heteroantagonism was more frequently observed $(80 \%)$, followed by autoantagonism (12\%) and isoantagonism (8\%). However, it is well known that the production of an antagonistic substance depends upon a number of physicochemical and nutritional conditions such as optimal temperature and $\mathrm{pH}$ and composition of the culture medium. The conditions for in vitro assay are far different from those found in the digestive ecosystems. Most of these antagonisms were performed by enterobacteria (48\%) and were principally concentrated in the stomach and in the proximal and median intestines. The antagonism of Gram negative microorganims was oriented against other Gram-negative bacteria (58\% of the case) and this fact was also observed for Grampositive bacteria $(61.5 \%)$. The fact that the antagonistic spectrum of the same bacterial species (S. epidermidis, A. bovis, $E$. agglomerans, E. fergusonii, E. coli) varied depending on the digestive portion of the isolation suggests that these microorganisms are different strains of the same species.

The analysis of the results presented in Table 2 furnish material for speculation about the eventual occurrence of one of more antagonistic substances produced by the isolated microorganisms, which would act in an auto-control of the bacterial population of the digestive tract of $C$. atratus, and also in maintaining the balance of the digestive ecosystem of the bird, regulating the inter- and intraspecific relations of the various bacterial members that compose the digestive tract microbiota of $C$. atratus. However, the antagonistic interrelationships observed in vitro must be confirmed in vivo.

As a final consideration, it is also important to remember that the microbial interactions are essential to the establishment and maintenance of any ecosystem. The presence of microorganisms capable of inhibiting the growth of other microorganisms in the digestive tract of the $C$. atratus raises the possibility of a potent barrier effect produced by the microorganisms present in the digestive tract of scavenger birds, which inhibits the implantation of colonies of pathogenic microorganism in such birds. These microorganisms may act as a factor that contributes to the notable resistance to pathogenic microorganisms and their toxins presented by vultures.

\section{ACKNOWLEDGMENTS}

This work was supported by Conselho Nacional de Desenvolvimento Científico e Tecnológico (CNPq). The authors would like to thank Dr. Edmar Chartone de Souza, Dr. Luiz Armando Cunha De Marco, Wolfanga Lentz M. Boson for helpful advice and Geraldo Leocádio Filho from Fundação Ezequiel Dias (FUNED) for supplying the media.

\section{RESUMO}

\section{Microbiota bacteriana dominante cultivável no trato digestivo do urubu (Coragyps atratus Bechstein 1793)}

As bactérias anaeróbias estritas e facultativas cultiváveis do trato digestivo de seis urubus (Coragyps atratus Bechstein 1793) foram isoladas e identificadas. Após a captura, as aves receberam uma alimentação de baixa contaminação durante uma semana para eliminar possíveis microorganismos alóctonos. A seguir, amostras colhidas na língua, estomago e intestinos foram pesadas, submetidas a diluições decimais numa câmara anaeróbia, inoculadas em meios de cultura e incubadas em aerobiose e anaerobiose a $37^{\circ} \mathrm{C}$ para enumeração, isolamento e identificação. As bactérias isoladas foram usadas posteriormente como produtoras e reveladoras para detectar possíveis fenômenos de antagonismo. A população bacteriana total ao longo do trato digestivo variou de $3,46 \pm 0,39 \mathrm{log} \mathrm{UFC} / \mathrm{g}$ no estômago até 10,75 $\pm 0,37 \log$ UFC/g no intestino distal. Algumas bactérias foram isoladas pela primeira vez do trato digestivo de C. atratus: Actinomyces bovis, Lactobacillus cellobiosus, Micrococcus luteus, Neisseria sicca, Clostridium bifermentans, Enterobacter agglomerans, Peptostreptococcus sp., Sarcina sp., Serratia odorifera, and Shigella flexneri. Associações entre microorganismos foram observadas durante o isolamento em dois casos, um envolvendo A. bovis e $N$. sicca, e o outro envolvendo A. bovis e um bastonete Gram-negativo. Hetero-, iso- e autoantagonismos foram observados, sugerindo um papel ecológico para esses microorganismos em termos de autocontrole populacional e de barreira ambiental no trato digestivo dessas aves.

Palavras-chave: urubu, microbiota, trato digestivo, substância antagonista.

\section{REFERENCES}

1. Barnes, E.M.; Impey, C.S. The isolation and properties of the predominant anaerobic bacteria in the caeca of chickens and turkeys. Brit. Poult. Sci., 11:467-481, 1970.

2. Barnes, E.M.; Mead, G.C.; Barnum, D.A.; Harry, E.G. The intestinal flora of the chicken in the period 2 to 6 weeks of age, with particular reference to the anaerobic bacteria. Brit. Poult. Sci., 13:311-326, 1972.

3. Corthier, G.; Dubos, F.; Raibaud, P. Modulation of cytotoxin production by Clostridium difficile in the intestinal tracts of gnotobiotic mice inoculated with various human intestinal bacteria. Appl. Environm. Microbiol., 49:250-252, 1985.

4. Ducluzeau, R.; Raibaud, P. Écologie microbienne du tube digestif. Masson S.A., Paris, 1979, 95p. 
5. Holt, J.G.; Krieg, N.R.; Sneath, P.H.A.; Williams, S.T. Bergey's manual of determinative microbiology. William and Wilkins, Baltimore, 1994, 787p.

6. Houston, D.C.; Cooper, J.E. The digestive tract of whiteback griffon vulture and its role in disease transmission among wild ungulates. $J$. Wildlif. Dis., 11:306-313, 1975.

7. Kalmback, E.R. American vultures and the toxin of Clostridium botulinum. J. Amer. Vet. Med. Assoc., 94:187-191, 1939.

8. Kelner, A. A method for investigating large microbial population for antibiotic activity. J. Bacteriol., 56:157-162, 1948.

9. Lev, M.; Briggs, C.A.E. Gut flora of the chick. III. Differences in cecal flora between "infected", "uninfected" and penicillin fed chicks. J. Appl. Bacteriol., 19:224-230, 1956.

10. Lincoln, R.E.; Lammana, C.; Foster, W.D. Enhanced sensitivity of germfree mice to the botulinal neurotoxin. Proc. Soc. Exp. Biol. Med., 139:1227-1230, 1972.

11. Livingstone, S.J.; Kominos, S.D.; Yee, R.B. New medium for selective and presumptive identification of the Bacteroides fragilis group. $J$. Clin. Microbiol., 7:448-453, 1978.

12. Mcatte, W.L. Relation of the turkey-buzzard to diseases of live stock. Auk, 30:295-298, 1913.
13. Moore, W.E.C.; Holdeman, L.V. Human fecal flora: the normal flora of 20 Japanese-Hawaiians. Appl. Microbiol., 27:961-979, 1974.

14. Naqi, S.A.; Lewis, D.H.; Hall, C.F. The intestinal microflora of turkeys. Av. Dis., 14:620-625, 1970.

15. Pessoa, G.V.A.; Silva, E.A.M. Meios de Rugai e lisina-motilidade combinados em um só tubo para identificação presuntiva de enterobactériaceas. Rev. Inst. Adolfo Lutz, 32:97-100, 1972.

16. Person, J.M. Bactériologie du tube digestif des carnivores. Rec. Méd. Vét., 158:37-45, 1982.

17. Raibaud, P.; Dickinson, A.B.; Sacquet, E.; Charlier, H.; Mocquot, G. La microflore du tube digestif du rat: techniques d'étude et milieux de culture proposés. Ann. Inst. Pasteur (Paris), 110:568-590, 1966.

18. Salanitro, J.P.; Blake, I.G.; Muirhead, P.A.; Maglio, M.; Goodman, J.R. Bacteria isolated from the duodenum, ileum, and cecum of young chicks. Appl. Environm. Microbiol., 35:782-790, 1978.

19. Schlatter, R.; Reinhardt, G.; Burchard, L. Estudio del jote (Coragyps atratus foetens, Lichtenstein) en Valdivia: Etologia carroñera y rol en diseminación de agentes patógenos. Arch. Med. Vet., 10:111-127, 1978.

20. Winsor, D.K.; Bloebaum, A.P.; Mathewson, J.J. Gram-negative, aerobic, enteric pathogens among intestinal microflora of wild turkey vultures (Cathartes aura) in west central Texas. Appl. Environm. Microbiol., 42:1123-1124, 1981. 